\title{
PERBANDINGAN KOMPRES HANGAT DAN KOMPRES DINGIN TERHADAP PERUBAHAN SKALA NYERI PADA IBU BERSALIN KALA I DI KLINIK PRATAMA MUTIARA BUNDA KAWALU KOTA TASIKMALAYA TAHUN 2016
}

\author{
Haryanti \\ HaryantiGC@,gmail.com
}

\section{A. ABSTRAK}

Jumlah kematian ibu di Indonesia tahun 2013 sejumlah 190 per 100.000 kelahiran hidup. Salah satu penyebab AKI yaitu persalinan lama yang disebabkan oleh faktor fisik, emosi, dan faktor sosial. Salah satu faktor emosi terjadinya partus lama adalah rasa cemas ibu yang tidak teratasi selama proses persalinan, rasa cemas tidak teratasi merupakan indikator terjadinya nyeri selama proses persalinan. Upaya untuk mengatasi nyeri persalinan adalah dengan memberikan kompres hangat dan dingin. Hasil studi pendahuluan di Klinik Pratama Mutiara Bunda Kawalu Kota Tasikmalaya sebagian besar ibu bersalin mengalami nyeri. Tujuan penelitian adalah untuk mengetahui perbandingan kompres hangat dan kompres dingin terhadap skala nyeri pada ibu bersalin kala I.

Metode penelitian ini adalah quasi eksperimen dengan rancangan Two Group Pretest Posttest Design. Populasi penelitian ini adalah seluruh ibu bersalin, teknik pengambilan sampel menggunakan teknik Accidental Sampling yaitu sebanyak 32 orang.

Hasil penelitian menunjukkan rata-rata nyeri sebelum diberikan kompres hangat ada pada kategori nyeri berat (62,5\%), setelah diberikan kompres hangat ada pada kategori nyeri ringan (43,8\%), dan rata-rata nyeri sebelum diberikan kompres dingin ada pada kategori nyeri berat (62,5\%), rata-rata nyeri sesudah diberikan kompres dingin ada pada kategori nyeri sedang (37,5\%). Berdasarkan hasil uji statistik diperoleh nilai signifikan kompres hangat sebesar 0,000 dan kompres dingin sebesar 0,006 yaitu lebih kecil dari nilai $\alpha(0,05)$, terdapat perbedaan antara kompres hangat dan dingin.

Dengan demikian, hasil penelitian membuktikan bahwa terapi kompres hangat lebih efektif menurunkan skala nyeri ibu bersalin dibandingkan kompres dingin. Hasil penelitian ini merekomendasikan kompres hangat untuk mengurangi nyeri pada ibu bersalin kala I persalinan.

Kata Kunci $\quad$ : Terapi kompres hangat, kompres dingin, nyeri 


\section{B. PENDAHULUAN}

Persalinan merupakan suatu proses fisiologis yang memungkinkan serangkaian perubahan yang besar pada ibu untuk dapat melahirkan janinnya melalui jalan lahir. Dimana persalinan dimulai sejak uterus berkontraksi dan menyebabkan perubahan pada serviks (membuka dan menipis) dan berakhir dengan lahirnya plasenta secara lengkap (Putri dkk, 2014). Meskipun persalinan merupakan proses yang fisiologis, tetapi masih ada beberapa komplikasi yang terjadi pada proses persalinan, seperti persalinan yang lama, posisi yang sulit, posisi sungsang, kembar, persalinan dengan penyulit, atau penyedotan dengan pompa (vacuum). Kondisi tersebut dapat mengakibatkan persalinan menjadi lama (Rose, 2006).

Angka Kematian Ibu (AKI) dan Angka Kematian Bayi (AKB) merupakan indikator paling penting dalam menentukan tingkat kesehatan masyarakat. Kesehatan Ibu dan Anak (KIA) masih menjadi masalah kesehatan di Indonesia merupakan yang tertinggi di ASEAN dengan jumlah kematian ibu tiap tahunnya mencapai 450 per 100.000 kelahiran hidup (profil Kesehatan Indonesia, 2011).

World Health Statistic 2014 oleh WHO juga menghitung jumlah kematian ibu di Indonesia pada tahun 2013 dan angka yang ditemukan sejumlah 190 per 100.000 kelahiran hidup. Penyebab kematian terbesar di Indonesia yaitu perdarahan $(30,1 \%)$, hipertensi $(26,9 \%)$, infeksi $(5,6 \%)$, partus lama $(1,8 \%)$, dan abortus $(1,6 \%)$. Diketahui bahwa partus lama merupakan komplikasi penyebab kematian ibu yang terbanyak nomor 4 di Indonesia (Pusdatin, Kemenkes RI, 2014).

Di Jawa Barat pada tahun 2015 terjadi kenaikan AKI sebanyak 823 jiwa dari 951.319 bayi lahir hidup, Provinsi Jawa Barat masih menjadi provinsi nomor satu penyumbang AKI. AKI disebabkan oleh penyebab langsung dan tidak langsung. Penyebab langsung AKI adalah perdarahan, hipertensi dalam kehamilan, infeksi, abortus, persainan lama dan lain-lain (Jurnal Posmedia, 2016). Salah satu daerah penyumbang kematian ibu yaitu kota Tasikmalaya dengan jumlah 20 jiwa (Dinkes Kota Tasikmalaya, 2015).

Salah satu penyebab AKI yaitu persalinan lama yang diantaranya disebabkan oleh penyebab tidak langsung yaitu faktor fisik, emosi, dan faktor sosial. Salah satu faktor emosi atau psikologis terjadinya partus lama adalah rasa cemas ibu yang tidak teratasi selama proses persalinan, rasa cemas yang tidak teratasi juga merupakan indikator terjadinya nyeri selama proses persalinan yang akan mempengaruhi kesehatan ibu dan bayi. Sebaliknya rasa nyeri selama persalinan juga menimbulkan kecemasan, sehingga stress, kecemasan, kekuatan, dan nyeri merupakan siklus yang berkesinambungan. Nyeri persalinan dialami oleh sebagian besar wanita, dengan rata-rata intensitas nyeri selama persalinan adalah $(8,83 \%)$ (Setyowati, 2013).

Nyeri persalinan adalah bagian dari proses normal dapat diprediksi munculnya nyeri yakni pada saat kehamilan timester III sehingga ada waktu untuk mempersiapkan diri dalam menghadapi persalinan, nyeri yang muncul adalah bersifat akut memiliki 
tenggang waktu yang singkat, munculnya nyeri secara intermitten dan berhenti jika proses persalinan sudah berakhir (Manurung, 2011).

Menurut Manurung (2011), penyebab nyeri dalam persalinan salah satunya adalah pada kala I yang disebabkan oleh meregangnya uterus dan terjadinya eficement (pendataran) dan dilatasi serviks. Bila nyeri tidak diatasi akan menyebabkan masalah yaitu stres pada ibu yang dapat menstimulasi tersekresinya katekolamin. Akibat tersekresi katekolamin maka terjadi insufisiensi uteroplasenter perfusi yang mengakibatkan terjadinya Fetal distress (Murray, 2007).

Berbagai upaya telah dilakukan untuk mengurangi nyeri pada persalinan, baik secara farmakologi maupun non-farmakologi. Managemen nyeri secara farmakologi lebih efektif dibanding dengan metode nonfarmakologi namun metode farmakologi membutuhkan biaya yang besar dan berpotensi mempunyai efek yang kurang baik, sedangkan metode non-farmakologi tidak membutuhkan biaya yang besar, simpel, efektif, dan tanpa efek yang merugikan (Manurung, 2011).

Terapi kompres hangat dan dingin merupakan salah satu metode nonfarmakologi untuk mengatasi nyeri, terapi ini perlu diberikan bagi semua ibu melahirkan sebagai salah satu intervensi terapi nyeri di pelayanan kesehatan, kompres hangat dapat meredakan iskemia dengan melancarkan pembuluh darah, sehingga dapat meredakan nyeri dengan mengurangi ketegangan dan meningkatkan perasaan sejahtera, dan meredakan vasokongesti pelvis yang akan menyebabkan pelebaran pembuluh darah dan meningkatkan aliran darah sedangkan teknik kompres dingin adalah suatu metode dalam penggunaan suhu rendah setempat yang dapat menimbulkan beberapa efek fisiologis, yaitu mengurangi aliran darah ke suatu bagian dan mengurangi perdarahan serta edema dan meningkatkan pelepasan endorfin yang memblok transmisi stimulus nyeri dan juga menstimulasi serabut saraf (Arum, 2015).

Berdasarkan hasil wawancara pada salah satu bidan pada tanggal 29 September 2016 di Klinik Pratama Mutiara Bunda Kawalu Kota Tasikmalaya didapatkan data jumlah persalinan dari Januari-Agustus 2016 kurang lebih sebanyak 116 ibu bersalin, pada bulan. Di Klinik Pratama Mutiara Bunda Kawalu Kota Tasikmalaya sebagian besar ibu bersalin mengalami nyeri persalinan kala I. Bidan mengatakan managemen nyeri pada proses persalinan dilakukan dengan cara non-farmakologi salah satunya dengan teknik relaksasi nafas dalam, namun bidanbelum melakukan intervensi non-farmakologi dengan teknik pemberian kompres hangat dan kompres dingin pada ibu bersalin dengan nyeri persalinan kala I.

Berdasarkan latar belakang di atas, peneliti tertarik mengambil judul mengenai "Perbandingan Pemberian Kompres Hangat dan Kompres Dingin Terhadap Perubahan Skala Nyeri Pada Ibu Bersalin Kala I di Klinik Pratama Mutiara Bunda Kawalu Kota Tasikmalaya". 


\section{METODOLOGI PENELITIAN}

\section{Desain Penelitian}

Jenis penelitian yang digunakan dalam penelitian ini adalah jenis penelitian eksperimen. Desain penelitian ini menggunakan Quasi Eksperimental dengan rancangan Two Group Pretest Posttest Design.

\section{Waktu dan Lokasi Penelitian}

Penelitian ini telah dilakukan di Klinik Pratama Mutiara Bunda Kawalu Kota Tasikmalaya pada bulan Oktober-November 2016.

\section{Subjek Penelitian}

Populasi dalam penelitian ini adalah jumlah ibu bersalin yang terdapat di Klinik Pratama Mutiara Bunda Kawalu Kota Tasikmalaya pada bulan Oktober-November tahun 2016 yang berjumlah 36 orang. Pengambilan sampel dalam penelitian ini menggunakan accidental sampling yaitu sebanyak 32 orang.

\section{Variabel Penelitian}

Variabel independen dari penelitian ini adalah kompres hangat dan kompres dingin dan variabel dependen adalah nyeri pada bu bersalin kala I.

\section{Instrumen Penelitian}

Instrumen penelitian ini berupa lembar instrumen dengan menggunakan Numeric Rating Scale (NRS).

\section{Analisa Data}

Analisis data yang digunakan dalam penelitian ini terdiri dari analisis univariat dan bivariat Rumus perhitungan untuk analisis univariat menggunakan rumus persentase, dengan rumus sebagai berikut:

$$
\mathrm{P}=\frac{\mathrm{X}}{\mathrm{N}} \times 100 \%
$$

Keterangan:

$\mathrm{P}$ : persentase

$\mathrm{X}$ : total skor yang didapat

$\mathrm{N}$ : total skor yang seharusnya

Sedangkan untuk uji bivariat menggunakan uji wilxocon, dengan rumus sebagai berikut :

$$
z=\frac{T-\mu_{T}}{\sigma_{T}}
$$




\section{PEMBAHASAN}

\section{Hasil Penelitian}

a.Analisis Univariat

1) Skala Nyeri paad Ibu Bersalin yang Menggunakan Kompres Hangat

Tabel 1

Distribusi Frekuensi Skala Nyeri pada Ibu Bersalin Kala I Sebelum dan Sesudah Diberikan

Kompres Hangat

di Klinik Pratama Mutiara Bunda Kawalu

Kota Tasikmalaya Tahun 2017

\begin{tabular}{|c|c|c|c|c|c|c|c|c|c|c|}
\hline \multirow{3}{*}{ Kompres hangat } & \multicolumn{9}{|c|}{ Skala Nyeri } \\
\cline { 2 - 12 } & \multicolumn{2}{|c|}{$\begin{array}{c}\text { Nyeri } \\
\text { ringan }\end{array}$} & \multicolumn{2}{c|}{$\begin{array}{c}\text { Nyeri } \\
\text { Sedang }\end{array}$} & \multicolumn{2}{c|}{$\begin{array}{c}\text { Nyeri } \\
\text { berat }\end{array}$} & \multicolumn{2}{c|}{$\begin{array}{c}\text { Nyeri } \\
\text { sangat } \\
\text { berat }\end{array}$} & \multicolumn{2}{c|}{ Total } \\
\cline { 2 - 12 } & F & \% & F & $\%$ & f & \% & f & $\%$ & f & $\%$ \\
\hline Sebelum & 0 & 0 & 2 & 12,5 & 10 & 62,5 & 4 & 25,0 & 16 & 100 \\
\hline Sesudah & 7 & 43,8 & 9 & 56,3 & 0 & 0 & 0 & 0 & 16 & 100 \\
\hline
\end{tabular}

Tabel 1 menunjukkan bahwa skala nyeri sebelum diberikan kompres hangat sebagian besar ada pada kategori nyeri berat sebanyak 10 orang $(62,5 \%)$, setelah diberikan kompres hangat sebanyak 9 orang $(56,3 \%)$ ada pada kategori nyeri sedang

2) Skala Nyeri pada Ibu Bersalin yang Menggunakan Kompres Dingin

Tabel 2

Distribusi Frekuensi Skala Nyeri pada Ibu Bersalin Kala I Sebelum dan Sesudah Diberikan Kompres Dingin di Klinik Pratama Mutiara Bunda Kawalu Kota Tasikmalaya Tahun 2017

\begin{tabular}{|c|c|c|c|c|c|c|c|c|c|c|}
\hline \multirow{3}{*}{$\begin{array}{c}\text { Kompres } \\
\text { hangat }\end{array}$} & \multicolumn{10}{|c|}{ Skala Nyeri } \\
\hline & \multicolumn{2}{|c|}{$\begin{array}{l}\text { Nyeri } \\
\text { ringan }\end{array}$} & \multicolumn{2}{|c|}{$\begin{array}{c}\text { Nyeri } \\
\text { Sedang }\end{array}$} & \multicolumn{2}{|c|}{$\begin{array}{l}\text { Nyeri } \\
\text { berat }\end{array}$} & \multicolumn{2}{|c|}{$\begin{array}{c}\text { Nyeri } \\
\text { sangat } \\
\text { berat }\end{array}$} & \multicolumn{2}{|c|}{ Total } \\
\hline & $\mathbf{F}$ & $\%$ & $\mathbf{F}$ & $\%$ & f & $\%$ & f & $\%$ & f & $\%$ \\
\hline Sebelum & 0 & 0 & 2 & 12,5 & 10 & 62,5 & 4 & 25,0 & 16 & 100 \\
\hline Sesudah & 10 & 62,5 & 6 & 37,5 & 0 & 0 & 0 & 0 & 16 & 100 \\
\hline
\end{tabular}

Tabel 2 menunjukkan bahwa skala nyeri sebelum diberikan kompres dingin sebagian besar ada pada kategori nyeri berat sebanyak 10 orang $(62,5 \%)$, setelah diberikan kompres dingin sebanyak 10 orang $(62,5 \%)$ ada pada kategori nyeri ringan. 
b. Analisis Bivariat

Tabel 3

Perbandingan Pemberian Kompres Hangat dan Kompres Dingin Terhadap Perubahan Skala Nyeri Pada Ibu Bersalin Kala I di Klinik Pratama Mutiara Bunda Kawalu Kota Tasikmalaya Tahun 2017

\begin{tabular}{|c|c|c|c|}
\hline Perlakuan & Mean rank & Sum of rank & p-value \\
\hline Kompres hangat & 8,50 & 136,0 & 0,000 \\
\hline Kompres dingin & 8,73 & 96,0 & 0,006 \\
\hline
\end{tabular}

Berdasarkan Tabel 3 menunjukkan bahwa terdapat perbedaan penurunan nyeri pada ibu bersalin kala I antara yang diberikan kompres hangat dan kompres dingin, dengan nilai $p$-value untuk kompres hangat adalah 0,000 dan nilai $p$-value untuk kompres dingin adalah 0,006 , jika nilai $\mathrm{p}$-value lebih kecil dari $(0,05)$, maka $\mathrm{H} 0$ ditolak artinya ada perbedaan penurunan nyeri pada ibu bersalin kala 1 antara yang menggunakan kompres hangat dengan kompres dingin di di Klinik Pratama Mutiara Bunda Kawalu Kota Tasikmalaya. Hasilnya menunjukkan bahwa pengaruh yang diberikan kompres hangat untuk menurunkan nyeri pada ibu bersalin kala I lebih kecil nilai p-valuenya, ini membuktikan bahwa kompres hangat lebih efektif untuk menurunkan nyeri pada ibu bersalin dibandingkan dengan kompres dingin.

\section{E. PEMBAHASAN}

\section{Skala Nyeri pada Ibu Bersalin Menggunakan Kompres Hangat}

Berdasarkan tabel 1 menunjukkan bahwa rata-rata nyeri sebelum diberikan kompres hangat pada ibu bersalin kala 1 di Klinik Pratama Mutiara Bunda Kawalu Kota Tasikmalaya ada pada kategori nyeri berat $(62,5 \%)$, sedangkan rata-rata nyeri sesudah diberikan kompres hangat ada pada kategori nyeri ringan $(43,8 \%)$. Hal ini menunjukan bahwa diberikan kompres hangat skala nyeri pada ibu bersalin menurun, sejalan dengan pendapat Potter \& Perry (2006) yang menyatakan bahwa pemberian kompres hangat menimbulkan efek hangat serta efek stimulasi kutaneus berupa sentuhan. Efek ini dapat menyebabkan terlepasnya endorphin, sehingga memblok transmisi stimulus nyeri. Adapun cara kerjanya yaitu ketika panas diterima reseptor, impuls akan diteruskan menuju hipotalamus posterior akan terjadi reaksi reflek penghambatan simpatis yang akan membuat pembuluh darah berdilatasi (Guyton \& Hall, 2007).

Penelitian yang dilakukan oleh Novitasari tahun 2011 menunjukkan bahwa ada pengaruh yang signifikan antara pemberian kompres panas terhadap nyeri persalinan kala I fase aktif dengan nilai $p=0,000$. Pemanasan merupakan metode sederhana yang digunakan pada ibu untuk meredakan rasa sakit. 11 stimulasi kulit melalui pemberian kompres ini dapat memberikan efek penurunan nyeri yang efektif karena kompres hangat juga akan menghasilkan efek fisiologis untuk tubuh yaitu efek vasodilatasi, peningkatan metabolisme sel dan merelaksasikan otot sehingga nyeri 
yang dirasa berkurang (Potter \& Perry, 2006).

a. Skala Nyeri pada Ibu Bersalin Menggunakan Kompres Dingin

Berdasarkan tabel 2 menunjukkan bahwa rata-rata nyeri sebelum diberikan kompres dingin pada ibu bersalin kala 1 di Klinik Pratama Mutiara Bunda Kawalu Kota Tasikmalaya ada pada kategori nyeri berat $(62,5 \%)$, sedangkan rata-rata nyeri sesudah diberikan kompres dingin ada pada kategori nyeri sedang $(37,5 \%)$. Kompres dingin juga efektif dalam menurunkan nyeri pada saat kala I persalinan, karena kompres dingin dapat meredakan nyeri dengan membuat area menjadi mati rasa, memperlambat aliran implus nyeri, meredakan perdarahan dan meningkatkan ambang nyeri ketegangan otot menurun yang berguna untuk menghilangkan nyeri, juga mengurangi ketegangan nyeri sendi dan otot, mengurangi pembengkakan, dan menyejukan kulit, kompres dingin akan membuat daerah yang terkena dengan memperlambat transmisi nyeri melalui neuron-neuron sensorik. Dengan menyebabkan vasokontraksi untuk menurunkan aliran darah ke daerah tubuh yang mengalami cedera juga mencegah terbentuknya edema, mengurangi inflamasi (Turlina \& Vilanti, 2013).

Namun tidak begitu perpengaruh banyak terhadap penurunannya. Pada saat penelitian, peneliti menemukan satu responden yang tidak mengalami penurunan nyeri, Pada saat ditanyakan, responden mengatakan bahwa pada saat di kompres ibu merasa tidak nyaman dan nyeri yang dirasakan tidak berkurang. Ini merupakan salah satu kelemahan dari penelitian ini, dimana alat ukur yang masih sangat objektif, variabel confounding yang belum dikendalikan seperti suku bangsa, kondisi psikologis, dukungan keluarga juga turut mempengaruhi hasil dari penelitian ini.

\section{b. Efektifitas Pemberian Kompres Hangat dan Kompres Dingin Terhadap Perubahan Skala Nyeri Pada Ibu Bersalin Kala I di Klinik Pratama Mutiara Bunda Kawalu Kota Tasikmalaya}

Berdasarkan tabel 3 menunjukan bahwa kompres hangat lebih efektif dibandingkan dengan kompres dingin, hal ini disebabkan bahwa kompres hangat bersifat vasodilatasi, yaitu meredakan nyeri dengan merelaksasi otot, meningkatkan aliran darah, memiliki efek sedatif dan meredakan nyeri dengan menyingkirkan produkproduk inflamasi yang menimbulkan nyeri. Hangat akan merangsang serat saraf yang menutup gerbang sehingga transmisi impuls nyeri ke medula spinalis dan ke otak dihambat dan dapat mempertahankan komponen system vaskuler dalam keadaan vasodilatasi sehingga sirkulari darah ke otot panggul menjadi homeostatis serta dapat mengurangi kecemasan dan kekuatan serta beradaptasi dengan nyeri selama peroses persalinan (Manurung, dkk, 2013).

Kompres air hangat sangat berperan dalam menghilangkan rasa nyeri ataupun untuk menormalkan fisiologi tubuh. Kompres hangat bermanfaat untuk meningkatkan suhu kulit lokal, melancarkan sirkulasi darah dan menstimulasi pembuluh darah, mengurangi spasme 5 otot dan meningkatkan ambang nyeri, menghilangkan sensasi rasa nyeri, merangsang peristaltik usus, pengeluaran getah radang serta memberikan ketenangan dan kenyamanan pada ibu inpartu (Simkin, 
2005). Saat yang paling melelahkan dan berat, dan kebanyakan ibu mulai merasakan sakit atau nyeri pada saat persalinan adalah kala I fase aktif. Penggunaan kompres hangat untuk area yang tegang dan nyeri dianggap mampu meredakan nyeri dan mengurangi spasme otot yang disebabkan oleh iskemia yang merangsang neuron yang memblok transmisi lanjut rangsang nyeri menyebabkan vasodilatasi dan peningkatan aliran darah ke area yang dilakukan pengompresan (Walsh, 2007).

Adapun juga kompres dingin berpengaruh terhadap nyeri persalinan, sebagaimana menurut (Turlina \& Vilanti, 2013), bahwa dengan diberikan kompres dingin meredakan nyeri dengan membuat area menjadi mati

\section{F. KESIMPULAN DAN SARAN}

\section{Kesimpulan}

a. Skala nyeri pada ibu bersalin kala 1 di Klinik Pratama Mutiara Bunda Kawalu Kota Tasikmalaya sebelum diberikan kompres hangat ada pada kategori nyeri berat $(62,5 \%)$, sedangkan sesudah diberikan kompres hangat ada pada kategori nyeri ringan $(43,8 \%)$.

b. Skala nyeri pada ibu bersalin kala 1 di Klinik Pratama Mutiara Bunda Kawalu Kota Tasikmalaya sebelum diberikan kompres dingin ada pada kategori nyeri berat $(62,5 \%)$, sedangkan sesudah diberikan kompres dingin ada pada kategori nyeri sedang $(37,5 \%)$.

c. Efektifitas penurunan skala nyeri pada ibu bersalin kala 1 antara yang mengunakan kompres hangat dengan kompres dingin di Klinik Pratama Mutiara Bunda Kawalu Kota rasa, memperlambat aliran implus nyeri, meredakan perdarahan dan meningkatkan ambang nyeri ketegangan otot menurun yang berguna untuk menghilangkan nyeri, juga mengurangi ketegangan nyeri sendi dan otot, mengurangi pembengkakan, dan menyejukan kulit, kompres dingin akan membuat daerah yang terkena dengan memperlambat transmisi nyeri melalui neuron-neuron sensorik. Namun perubahannya tidak begitu banyak dirasakan oleh ibu bersalin, dikarnakan banyak faktor yang menyebabkan nyeri, diantaranya ketidaknyamanan ibu diberikan kompres dingin, melainkan ibu lebih nyaman diberikan kompres hangat karena ibu merasakan kenymanan dan ibu menjadi relaksasi.

Tasikmalaya yaitu lebih efektif menggunakan kompres hangat.

\section{Saran}

Merekomendasikan kepada petugas kesehatan untuk melakukan kompres pada setiap ibu bersalin kala I untuk meminimalisir nyeri saat persalinan. Setiap ibu bersalin dan keluarga mampu mengaplikasikan teknik kompres hangat secara mandiri untuk meminimalisir nyeri pada saat kala I persalinan.

\section{G. DAFTAR PUSTAKA}

Andarmoyo \& Suhasti. (2013) Bersalin Tanpa Nyeri Berlebihan. Jogjakarta : AR-RUZZ.

Asmadi. (2008). Teknik Prosedural Keperawatan. Jakarta : Salema Medika. 
Asrinah, dkk. (2010). Masa Persalinan. Yogyakarta : Graha Ilmu.

Budiharto. (2008). Metodologi Penelitian Kesehatan dengan Contoh Bidang Ilmu Kesehatan Gigi. Jakarta : EGC

D, Kusum. (2011). Metodologi Penelitian Keperawatan . Jawa Timur : CV Trans Info Media.

Felina, dkk (2015). Pengaruh Kompres Panas dan Dingin Terhadap Penurunan Nyeri Kala I Fase Aktif Persalinan Fisiologis Ibu Primipara, Tersedian Dalam: jurnal.fk.unand.ac.id/index.php/jka/ article/download/190/185

H, Asri. (2010). Asuhan Persalinan Normal. Yogyakarta : Nuha Medika.

Hasan, Ikbal. (2006). Analisis Data Penelitian Dengan Statistik. Jakarta : Bumi Aksara. Jepara : Badan Pusat Statistik.

Hidayat, A (2007). Metode Penelitian Keperawatan Dan Teknik Analisis Data Jakarta : Salemba Medika.

Irmawati. (2014). Tetap Tersenyum Saat Melahirkan. Yogyakarta : Media Presindo.

Judha, M. (2012). Teori Pengukuran Nyeri dan Nyeri Persalinan. Yogyakarta : Muha

Manurung, S. dkk. (2013). Pengaruh Teknik Pemberian Kompres Hangat Terhadap Peubahan Skala Nyeri Persalinan Pada Klien Primigravida. Jurnal Health Qualiti.

Muray, S.S \& Mc.Kiney, E.S. (2007). Foundation Of Maternal Neouborn Nursing. Philipins : Saunders.
Notoatmodjo, S (2010). Metodologi Penelitian Kesehatan. Jakarta : Rineka Cipta.

Nurlina dan Valenti (2013). Pengaruh Kompres Dingin Terhadap Penurunan Nyeri Persalinan Kala I Fase Aktif, di BPS Ny. Mujiyati Kabupaten Lamongan, Tersedi adalam:

http://analis.say.ac.id/ejournal/ind ex.php/jkk/article/viewFile/90/86.

Nursalam. (2008). Konsep dan Penerapan Metodologi Penelitian Ilmu Keperawatan. Jakarta : Salemba Medika.

Potter \& Perry. (2006). Buku Ajar Pundamental Keperawatan. Jakarta : EGC

Pusdatin, Kemenkes RI. (2014). Kesehatan Ibu dalam Mothers Day. Jakarta Selatan.http://www.depkes.go.id/r esources/download/pusdatin/infod atin/infodatin-ibu.pdf

Sugiyono. (2007). Metode Penelitian Kualitatip Kuantitatif dan $R \& D$. Bandung: Alfabeta. 